\title{
Contributions to the distribution of Phallales in Turkey
}

\section{Ant J Bot} He

Received : 18.07.2019

Accepted : 12.08 .2019

Online $: 15.08 .2019$
Semiha YAKAR $\odot$, Yasin UZUN* ${ }^{*}$, Abdullah KAYA๑

Karamanoğlu Mehmetbey University, Kamil Özdăg Science Faculty, Department of Biology, Karaman, Turkey *yasinuzun_61@hotmail.com

\section{Türkiye'deki Phallales'lerin yayılışına katkılar}

Abstract: New specimens of four previously reported members of the family Phallaceae, Clathrus ruber P.Micheli ex Pers. Mutinus caninus (Huds.) Fr., Phallus impudicus L., and Pseudocolus fusiformis (E. Fisch.) Lloyd, were collected from Eastern Black Sea region of Turkey. The samples were identified and brief descriptions were prepared. Current and newly determined localities of the collected species were provided together with the photographs related to their macro and micromorphologies.

Key words: Biodiversity, Phallaceae, stinkhorn fungi, Turkey.

Özet: Doğu Karadeniz Bölgesi'nden, daha önceden rapor edilmiş olan dört Phallaceae familyası üyesine, Clathrus ruber P.Micheli ex Pers., Mutinus caninus (Huds.) Fr., Phallus impudicus L., ve Pseudocolus fusiformis (E. Fisch.) Lloyd, ait yeni örnekler toplanmıştır. Örneklerin teşhisleri yapılmış ve kısa betimleri hazırlanmıştır. Toplanan türlerin mevcut ve yeni belirlenen lokaliteleri, makro ve mikromorfolojilerine ait fotoğrafları ile birlikte verilmiștir.

Anahtar Kelimeler: Biyoçeşitlilik, Phallaceae, pis kokulu mantarlar, Türkiye

\section{Introduction}

Phallales E.Fisch. is an order of fungi in the phylum Basidiomycota. Acccording to Kirk et al., (2008) the order comprises 88 species belonging to 26 genera and 2 families, but Index Fungorum (accessed 10 June 2019) currently list 173 taxa within 39 genera. Phallaceae Corda is a well-known family of the order Phallales and commonly known as "stinkhorns". Members of the family are generally characterized by a simple hollow pseudostipe and a slimy spore mass which is usually supported by a campanulate receptacle or spread over the pseudostipe surface (Gaona et al., 2017).

Until the end of 2018, 44 records, belonging to 7 species of the Phallaceae within the genera Anthurus Kalchbr. \& MacOwan, Clathrus P.Micheli ex L., Colus Cavalier \& Séchier, Mutinus Fr., Phallus Junius ex L. and Pseudocolus Lloyd have so far been presented from Turkey (Sesli and Denchev, 2014; Akata and Gürkanll, 2018). These samples were collected from 30 different provinces of Turkey. During our routine field studies fruit bodies of stinkhorn species were collected from Eastern Black Sea Region of Turkey and determined as Clathrus ruber P. Micheli ex Pers., Mutinus caninus (Huds.) Fr., Phallus impudicus L., and Pseudocolus fusiformis (E. Fisch.) Lloyd.

The study aims to make a contribution to the mycobiota of Turkey by presenting new distributions for some stinkhorn fungi.

\section{Materials and Method}

Stinkhorn fungi samples were collected from Artvin, Giresun, Rize and Trabzon provinces during routine field studies between 2015 and 2018 within the Eastern Black Sea Region of Turkey. Required characteristics of the samples were recorded and they were photographed in their natural habitat. The samples were dried in air conditioned room and prepared as fungarium materials. Measuremental evaluations were performed in the fungarium. Micromorphological investigations were carried out under a Nikon eclipse $\mathrm{Ci}$-S trinocular light microscope and the photographs related to micromorphology were taken by a DS-Fi2 digital camera aided by a Nikon DS-L3 displaying apparatus. The specimens were identified with the help of Bessette et al., (1995, 1997), Philips (2010), McKnight and McKnight (1987), Sterry and Hughes (2009), Buczacki (2012), Lincoff, (1981), Pegler et al., (1995), Roberts and Evans (2013), Watling (1973), Akata and Doğan (2011), Miller and Miller (1988), Jordan (1995), Breitenbach and Kränzlin (1986) and Ellis and Ellis (1990).

The specimens are deposited at Biology Department, Kamil Özdağ Science Faculty, Karamanoğlu Mehmetbey University.

\section{Results}

Basidiomycota R.T.Moore

Phallales E.Fisch.

Phallaceae Corda

Clathrus P.Micheli ex L.

Clathrus ruber P.Micheli ex Pers., Syn. meth. fung. (Göttingen) 2: [241] (1801).

[Syn: Clathrus cancellatus Tourn. ex Fr., Clathrus cancellatus c albus Fr., Clathrus flavescens Pers., Clathrus kusanoi (Kobayasi) Dring, Clathrus ruber * columnatus Schwein., Clathrus ruber f. kusanoi Kobayasi, Clathrus ruber P. Micheli ex Pers. f. ruber, Clathrus ruber var. albus (Fr.) Quadr. \& Lunghini, Clathrus ruber var. flavescens (Pers.) Quadr. \& Lunghini, Clathrus ruber P. Micheli ex Pers. var. ruber]

Macroscopic and microscopic features: Immature fruit body 30-60 mm in diam., egg-shaped (Figure 1a), subhypogeous to epigeous, consists of an olive-green gleba, a compressed lattice surrounding the gleba (Figure 1b), and a white to creamy and leathery outer membrane (exoperidium), enclosing the gleba and the lattice. Surface 
smooth, marked by reticulations indicating the site of insertion of the lattice (Figure 1a), and rooted by a thick mycelial strand at the base (Figure 1b,c). Later on the peridium ruptures at the apex letting the lattice-shaped receptaculum rise (Figure 1c). Receptaculum 90-120 × 65-85 mm, hollow, spherical to globose or somewhat elongated lattice-like network of meshes (Figure 1c,d); arms about $15 \mathrm{~mm}$ thick with a spongy structure, salmonpink to scarlet red, somewhat paler towards the base. The mature fruit body smells like a carrion. Basidia and cystidia not observed. Basidiospores 4.5-6 × 1.5-2 $\mu \mathrm{m}$, cylindrical to bacilloid, hyaline to pale greenish, smooth, thin-walled (Figure 1e).

Clathrus ruber was reported to grow on soil amongst leaf litter in gardens, shrubberies and grassy places at the edge of woodlands (Breitenbach and Kränzlin, 1986; Jordan, 1995; Pegler et al., 1995).

Clathrus ruber is the only clathroid species of Clathrus known in Turkey.

Specimen examined: Rize, Ardeşen, Ortaalan village, roadside, on soil, $41^{\circ} 10^{\prime} \mathrm{N}-41^{\circ} 06^{\prime} \mathrm{E}, 340 \mathrm{~m}, 09.07 .2017$,

Yuzun 5637; Güneyköy village, roadside and bean garden, on soil, $41^{\circ} 08^{\prime} \mathrm{N}-41^{\circ} 07^{\prime} \mathrm{E}, 860 \mathrm{~m}, 11.08 .2017$, Yuzun 5741; Pazar, Hasköy village, house garden, on soil, $41^{\circ} 06^{\prime} \mathrm{N}-40^{\circ} 51^{\prime} \mathrm{E}, 420 \mathrm{~m}$, Yuzun 6968; Trabzon, Tonya, Hoşarlı village, around bean garden, on soil, $40^{\circ} 56^{\prime} \mathrm{N}$ $39^{\circ} 18^{\prime} \mathrm{E}, 740 \mathrm{~m}, 22.05 .2016$, Yuzun 5129; Karaağaçlı village, hazelnut garden, on soil, $40^{\circ} 55^{\prime} \mathrm{N}-39^{\circ} 17^{\prime} \mathrm{E}, 640 \mathrm{~m}$, 20.06.2016, Yuzun 5147.

Clathrus ruber was reported previously from fourteen localities in Antalya, Aydın, İstanbul, İzmir, Kahramanmaraş, Kocaeli, Muğla, Osmaniye, Samsun, Sinop, Trabzon, Uşak, and Yalova province (Afyon and Yağız, 2004; Allı et al., 2007; Baydar and Sesli, 1994; Pekşen and Karaca, 2003; Günay and Demirel, 2006; Türkoğlu and Yağız, 2012; Akata et al., 2014, 2018; Solak and Y1lmaz Ersel, 2005; Y1lmaz Ersel and Solak, 2004; Solak et al., 2014; Kaya, 2009; Ünal et al., 2016; Allı et al., 2017; Güngör et al., 2016; Akata, 2017).

\section{Mutinus Fr.}

Mutinus caninus (Huds.) Fr., Summa veg. Scand., Sectio Post. (Stockholm): 434 (1849).
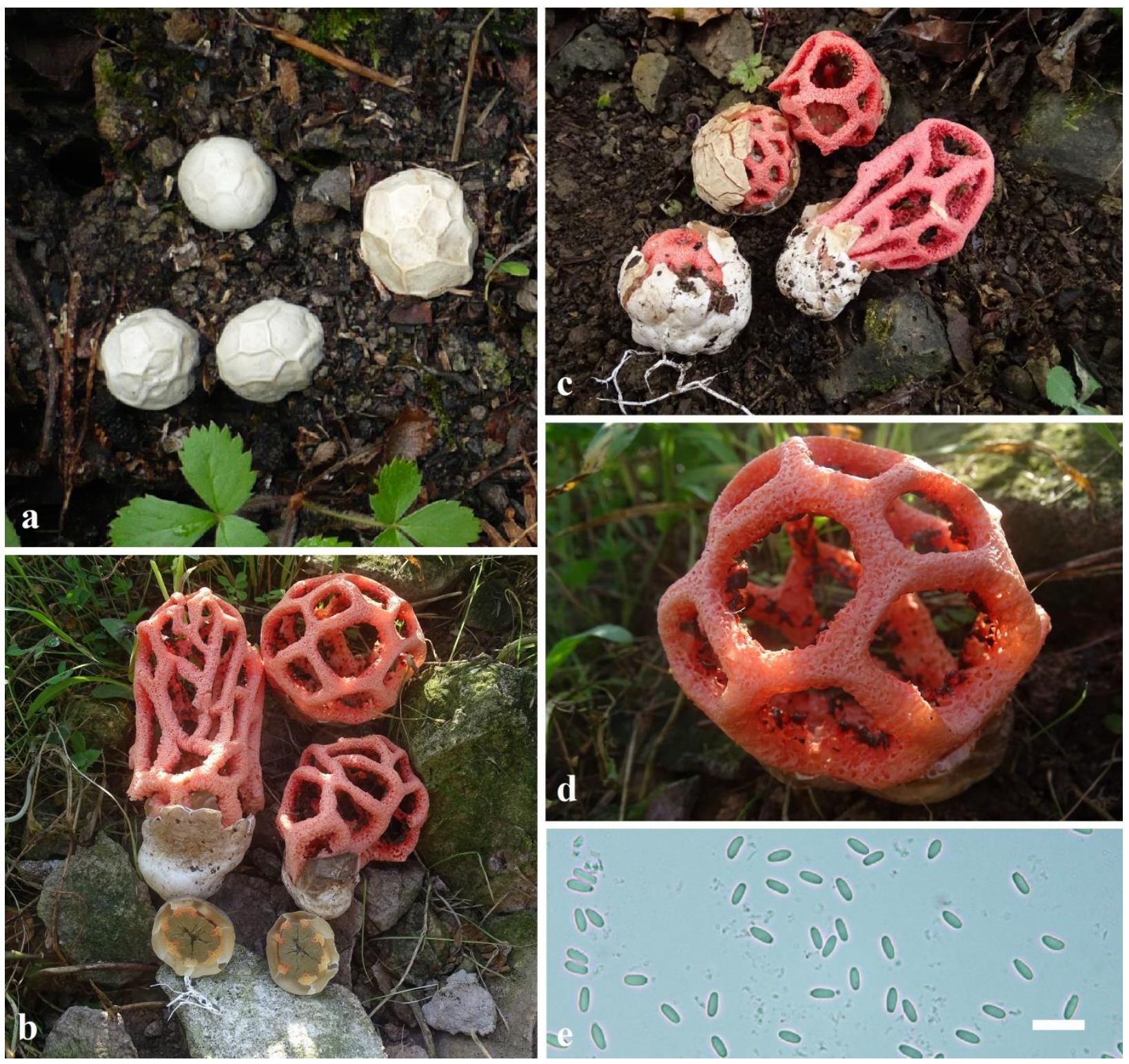

Figure 1. Basidiocarps (a-d) and basidiospores (e) of Clathrus ruber (bar $10 \mu$ ). 
[Syn: Aedycia canina (Huds.) Kuntze, Cynophallus caninus (Huds.) Fr., Ithyphallus inodorus Gray, Mutinus caninus var. albus Zeller, Mutinus caninus (Huds.) Fr. var. caninus, Mutinus caninus var. levonensis Noelli, Phallus caninus Huds., Phallus caninus Huds. var. caninus, Phallus caninus var. felina Schumach., Phallus inodorus Sowerby]

Macroscopic and microscopic features: Immature fruitbody 15- $35 \times 15-30 \mathrm{~mm}$, elongate ovoid to pyriform or egg shaped, at first hypogeous then epigeous, white to dirty white or yellowish rubbery outer exoperidium encloses the gelatinous endoperidium in which the pale green embryonic spore mass (gleba) and the stalk (receptacle) are kept, basally attached by a white rhizomorph (Figure 2a,b). Following the rupture of the egg, the receptacle becomes volvate (Figure 2d). Receptacle $90-120 \times 10-15 \mathrm{~mm}$, cylindrical to tapering above, hollow, spongy, brick-red to orange-red, somewhat paler towards the base. Olive green to dark greyish and slimy-soft glebiferous dissapears in a short time and leaves the empty, orange-brown glebal chambers (Figure 2c,d). Basidia cylindrical, 6-spored. Cystidia not observed. Basidiospores 3.5-5 × 1-2 $\mu \mathrm{m}$, cylindrical to ellipsoid, smooth, hyaline (Figure 2e).
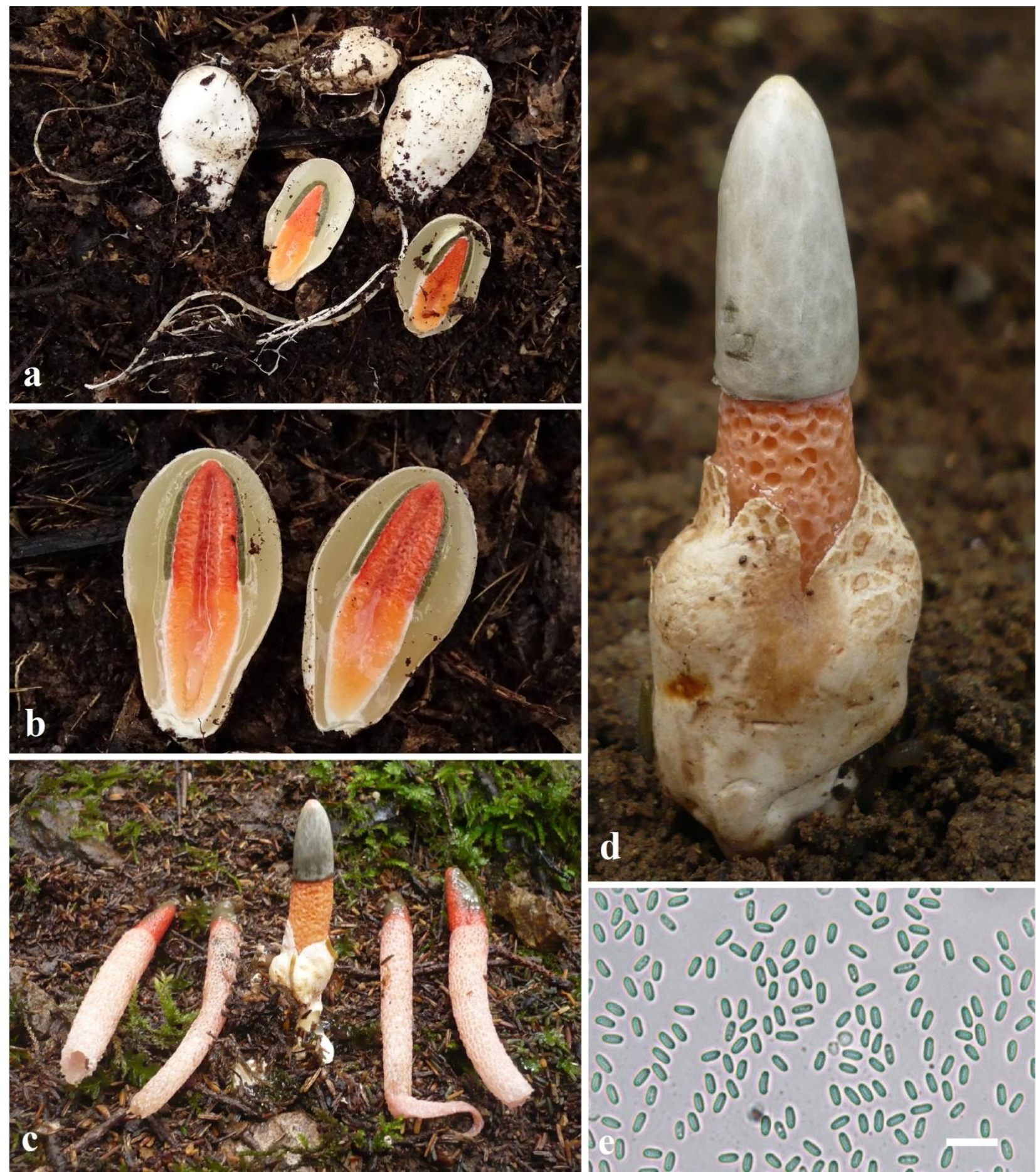

Figure 2. Basidiocarps (a-d) and basidiospores (e) of Mutinus caninus (bar $10 \mu$ ). 
Mutinus caninus grows on soil amongst leaf litter, around decaying stumps or rarely on rotting woods generally in hardwood forest and more rarely in conifer forests (Breitenbach and Kränzlin, 1986; Jordan, 1995; Pegler et al., 1995).

Specimen examined: Trabzon, Yomra, Özdil Village, on soil and dead plant residues, under Fagus orientalisCastanea sativa-Rhododendron ponticum mixed forest, $40^{\circ} 50^{\prime} \mathrm{N}-39^{\circ} 48^{\prime} \mathrm{E}, 1210 \mathrm{~m}, 25.08 .2018$, Yuzun 6682; Arakl1, near rifle range, on soil and dead plant residues, under Castanea and Corylus sp, $40^{\circ} 56^{\prime} \mathrm{N}-40^{\circ} 02^{\prime} \mathrm{D}, 195 \mathrm{~m}$, 04.12.2018, Yuzun 6929.

Mutinus caninus was reported previously from Turkey twelve times from nine localities in Artvin, Bolu, Gümüşhane, İstanbul, Kastamonu, Kocaeli Samsun, Trabzon and Yalova province (Demirel and Uzun, 2004; Yağız et al., 2006a; Akata et al., 2010, 2014, 2016, 2018; Pekşen and Karaca, 2003; Sesli, 2007; Allı et al., 2017; Akata, 2017).

Phallus Junius ex L.

Phallus impudicus L., Sp. pl. 2: 1178 (1753).

[Syn: Dictyophora duplicata var. obliterata Malençon, Hymenophallus togatus Kalchbr., Ithyphallus impudicus (L.) Fr., Ithyphallus impudicus var. carneus Lemmerm., Ithyphallus impudicus (L.) Fr. var. impudicus, Ithyphallus mauritianus (Lloyd) Sacc. \& Traverso, Kirchbaumia imperialis Schulzer, Morellus impudicus (L.) Eaton, Phallus foetidus Sowerby, Phallus impudicus f. adiscus Houda, Phallus impudicus f. alveolata Ulbr., Phallus impudicus f. flavida Henn., Phallus impudicus L. f. impudicus, Phallus impudicus f. reticulata Ulbr., Phallus impudicus f. subindusiatus Pilát, Phallus impudicus f. togatus (Kalchbr.) Quél., Phallus impudicus var. americanus Ulbr., Phallus impudicus var. carneolus Houda, Phallus impudicus var. imperialis (Schulzer) Ulbr., Phallus impudicus L. var. impudicus, Phallus impudicus var. pseudoduplicatus O. Andersson, Phallus impudicus var. subindusiatus (Pilát) Lécuru, Phallus impudicus var. togatus (Kalchbr.) Costantin \& L.M. Dufour, Phallus impudicus var. vulgaris Ulbr., Phallus mauritianus Lloyd, Phallus volvatus Batsch.]

Macroscopic and microscopic features: Immature fruit body $30-55 \mathrm{~mm}$ in diam., globose to ovoid (Figure $3 \mathrm{a}, \mathrm{b}$ ), sub-hypogeous to epigeous, white to pale cream, smooth exoperidium covers the gelatinous, translucent endoperidium, the olive-green gleba with the whitish glebal chambers, and in the compressed white receptacle, attached with a stout, white, mycelial cord (Figure 3c). Later on the peridium ruptures and the gleba is lifted up by the elongation of the stalk. Receptacle 140-200 × 14-30 $\mathrm{mm}$, volvate, cylindrical, hollow, fragile, spongy, tapering upward. Pileus glebiferous, attached to the apical portion of the stak, campanulate, externally pale grey to brownish, reticulate-costate with a truncated apical disc (Figure 3d). Gleba becomes mucilaginous, translucent, greenish black to dark olive-green, with strong foetid odour at maturity. Basidia clavate, 6-spored. Cystidia not observed. Basidiospores 3.5-5 × 1.5-2 $\mu \mathrm{m}$, ellipsoid, smooth, pale olive (Figure 3e).

Phallus impudicus was reported to grow on soil among leaf litter in hardwood and coniferous forest (Watling,
1973; Breitenbach and Kränzlin, 1986; Jordan, 1995; Pegler et al., 1995; Sterry and Hughes, 2009).

Specimen examined: Artvin, Borçka, Aralık village, Fagus-Rhododendron-Alnus-Corylus mixed forest, on soil, $41^{\circ} 23^{\prime} \mathrm{N}-41^{\circ} 44^{\prime} \mathrm{E}, 580 \mathrm{~m}, 24.06 .2015$, Yuzun 4202; Rize, Ardeşen, Eskiarmutluk village, on soil, under $F$. orientalis-C. sativa- $R$. ponticum mixed forest, $41^{\circ} 07^{\prime} \mathrm{N}$ $41^{\circ} 08^{\prime} \mathrm{E}, 610 \mathrm{~m}, 05.08 .2016$, Yuzun 5184; Trabzon, Tonya, Erikbeli village, on soil, under F.orientalis-C. sativa- $R$. ponticum mixed forest, $40^{\circ} 45^{\prime} \mathrm{N}-39^{\circ} 14^{\prime} \mathrm{E}, 1680$ $\mathrm{m}, 22.09 .2015$, Yuzun 4606.

Phallus impudicus was reported previously from Antalya, Aydın, Balıkesir, Bingöl, Bitlis, Bolu, Denizli, Elazığ, Gümüşhane, Hatay, İstanbul, İzmir, Kastamonu, Kayseri, Kocaeli, Malatya, Mersin, Muğla, Samsun, Trabzon and Uşak (Vlaev, 1915; Gücin, 1990; Işıloğlu ve Öder, 1995a,b; Aşkun ve Işıloğlu, 1997; Işıloğlu, 1997; 2001; Kaya, 2000; Kaş1k et al., 2002; Solak et al., 2002; Öztürk et al., 2003; Pekşen ve Karaca, 2003; Y1lmaz Ersel and Solak, 2004; Yağız et al., 2006a; 2006b; Sesli, 2007; Allı et al., 2006, 2007; Türkoğlu, 2008; Türkoğlu and Yağız, 2012; Baba et al., 2013, 2014; Akata et al., 2014, 2016, 2018; Güngör et al., 2016; Uzun et al., 2017; Akata, 2017).

\section{Pseudocolus Lloyd \\ Pseudocolus fusiformis (E. Fisch.) Lloyd}

[Syn: Anthurus javanicus (Penz.) G. Cunn., Anthurus rothae (Berk. ex E. Fisch.) E. Fisch., Colus elegans Welw., Colus fusiformis E. Fisch., Colus javanicus Penz., Colus rothae Berk. ex E. Fisch., Colus rothae (Lloyd) Sacc. \& Traverso, Colus schellenbergiae Sumst., Pseudocolus javanicus (Penz.) Lloyd, Pseudocolus rothae (Berk. ex E. Fisch.) Yasuda, Pseudocolus rothae Lloyd, Pseudocolus schellenbergiae (Sumst.) M.M. Johnson]

Macroscopic and microscopic features: Immature fruit body $20-30 \times 20-30 \mathrm{~mm}$, egg-shaped or pear-shaped, grayish brown to pale gray or rarely whitish exoperidium covers the gelatinous endoperidium, receptacle and the olive green glebal content, attached to the substrate with white rhizomorphs at the base (Figure 4a,b). The peridium ruptures at maturity letting the receptacle come up. Stalk 40-70 mm, volvate, divided into 3-4 vertical columns which are tapered upwards and generally united at the apex, whitish at the base, orange, pink or red above. Gleba born on the inner side of the arms, slimy, drying nearly black. olive-green to dark green, borne on the inner side of the arms, slimy, foulsmelling, drying nearly black (Figure 4c,d). Basidiospores 3.5-5 × 1.5-2.5 $\mu \mathrm{m}$, ellipsoidovoid, smooth (Figure 4e).

Pseudocolus fusiformis grows on soil or among wood chips in gardens, in coniferous or mixed forest (Bessette et al., 1995; Phillips, 2010).

Specimen examined: Giresun, Dereli, Akkaya village, hazelnut garden, on wood shavings and dead hazelnut husks, $40^{\circ} 43^{\prime} \mathrm{N}-38^{\circ} 23^{\prime} \mathrm{E}, 865 \mathrm{~m}, 18.10 .2017$, Yuzun 5915; Rize, Ardeşen, Yeniyol village, near the road of mixed forest, on soil and wood shavings, $41^{\circ} 13^{\prime} \mathrm{N}-41^{\circ} 03^{\prime} \mathrm{E}, 530$ m, 06.08.2016, Yuzun 5192; Trabzon, Tonya, Sayraç village, hazelnut garden, on soil and wood shavings, $40^{\circ} 54^{\prime} \mathrm{N}-39^{\circ} 14^{\prime} \mathrm{E}, 945 \mathrm{~m}, 28.08 .2015$, Yuzun 4525. 

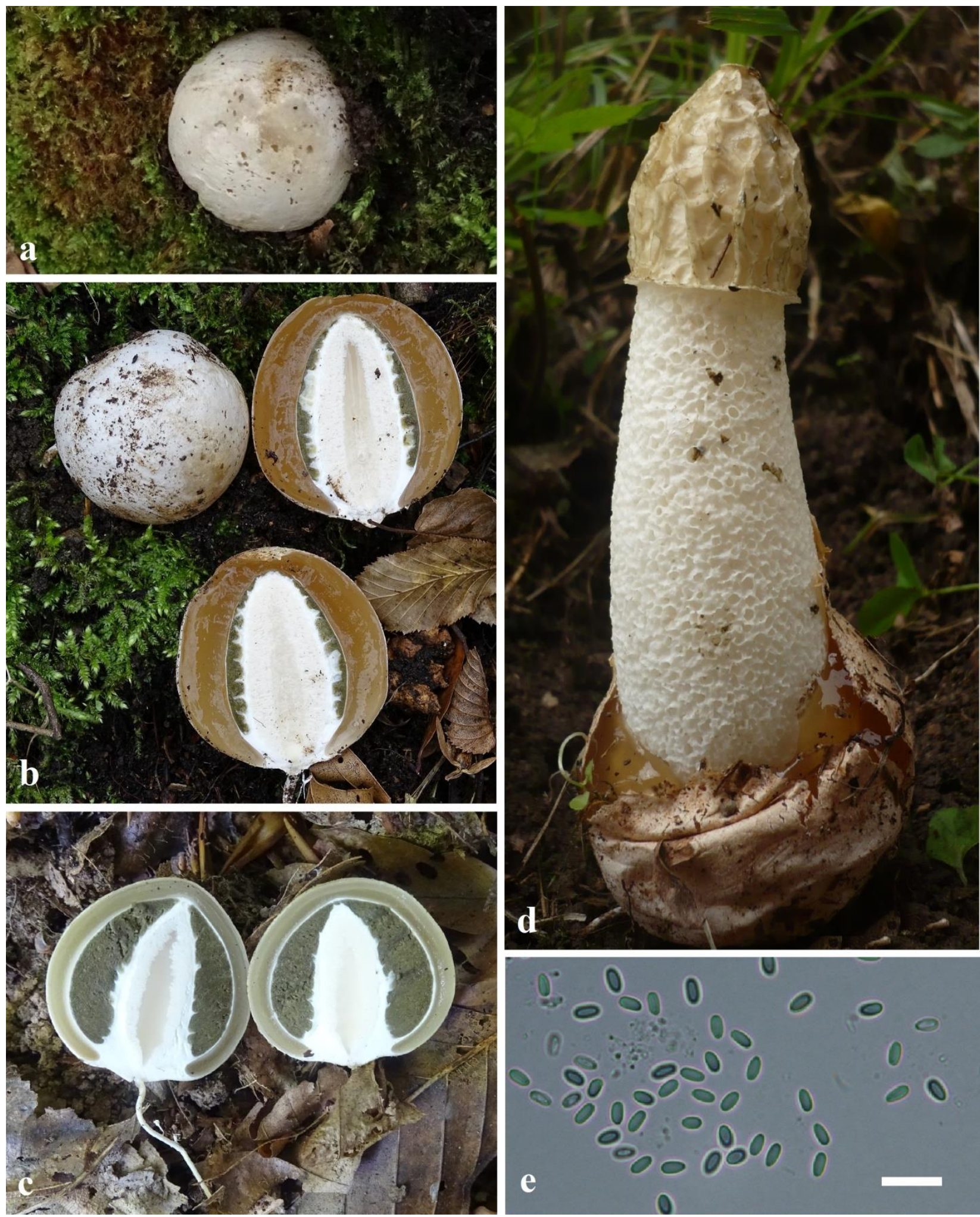

Figure 3. Basidiocarps (a-d) and basidiospores (e) of Phallus impudicus (bar $10 \mu$ ).

Pseudocolus fusiformis was reported previously from only one locality in Trabzon (Akata ve Doğan, 2011).

\section{Discussions}

New localities were added to the existing localities of four stinkhorn species within the boundaries of Artvin, Giresun, Rize and Trabzon provinces. Pseudocolus fusiformis was previously reported only from Yomra district of Trabzon province. Three new localities were also presented within Giresun, Rize and Trabzon provinces. Mutinus caninus have 9 previously presented localities in Turkey. Two new localities were added in Trabzon. Compared to previous two species, Clathrus ruber seems to have more distribution in Turkey. This species were previously reported from 13 provinces of Turkey. Five new distribution localities were also presented for it in Rize and Trabzon provinces. Phallus impudicus is the most cosmopolitan species in Turkey 

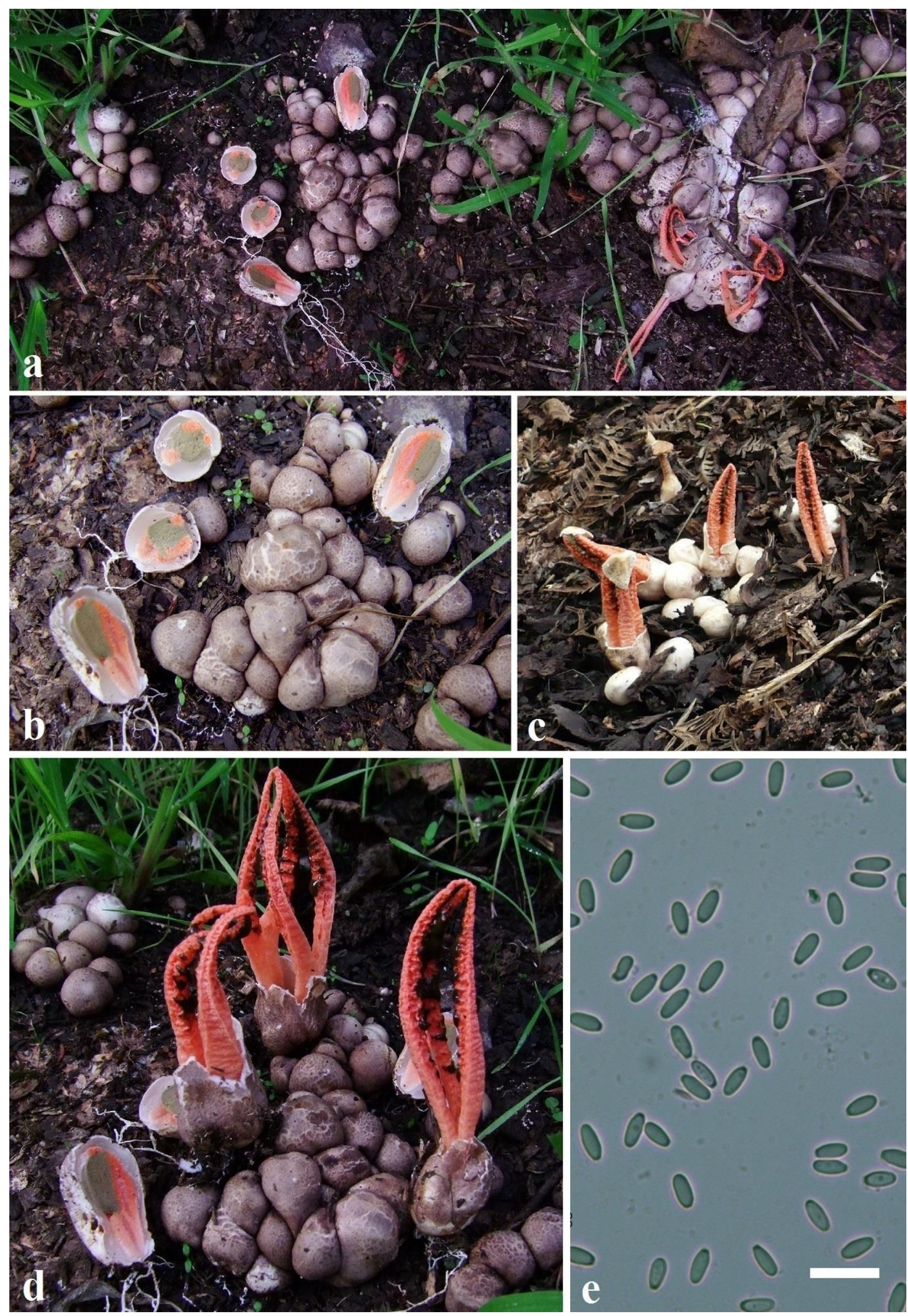

Figure 4. Basidiocarps (a-d) and basidiospores (e) of Pseudocolus fusiformis (bar $10 \mu$ ). 
among the four taxa. This species has been cited in 33 studies carried out within the boundaries of 21 provinces of Turkey. Two new localities were also presented for this species from Artvin and Rize provinces from which it was not reported before.

\section{Acknowledgments}

Authors would like to thank Karamanoğlu Mehmetbey University Research Fund (Project No: 02-M-15 and 16M-16) for its financial support.

\section{References}

Afyon A, Yağız D (2004). Macrofungi of Sinop Province. Turkish Journal of Botany 28(4): 351-360.

Akata I (2017). Macrofungal Diversity of Belgrad Forest (İstanbul). Kastamonu Üniversitesi Orman Fakültesi Dergisi 17(1): 150164.

Akata I, Çetin B, Işıloğlu M (2010). Macrofungal diversity of Ilgaz Mountain National Park and its environs (Turkey). Mycotaxon 113: 287-290.

Akata I, Doğan HH (2011). Pseudocolus fusiformis, an uncommon stinkhorn new to Turkish mycobiota. Mycotaxon 115: 259262.

Akata I, Gürkanlı CT (2018). A New Genus Record For Turkish Clathroid Fungi. The Journal of Fungus 9(1): 36-38.

Akata I, Kabaktepe Ş, Sevindik M, Akgül H (2018). Macrofungi determined in Yuvacik Basin (Kocaeli) and its close environs. Kastamonu Üniversitesi Orman Fakültesi Dergisi 18(2): 152-163.

Akata I, Uzun Y, Kaya A (2014). Macromycetes determined in Yomra (Trabzon) district. Turkish Journal of Botany 38(5): 9991012.

Akata I, Uzun Y, Kaya A (2016). Macrofungal diversity of Zigana Mountain (Gümüşhane/Turkey). Biological Diversity and Conservation 9(2): 57-69.

Allı H, Candar SS, Akata I (2017). Macrofungal Diversity of Yalova Province. The Journal of Fungus 8(2): 76-84.

Allı H, Işıloğlu M, Solak H (2006). Aydın Yöresinin Yenen Mantarları. Selçuk Üniversitesi Fen-Edebiyat Fakültesi Fen Dergisi 28: 83-92.

Allı H, Işıloğlu M, Solak MH (2007). Macrofungi of Aydın Province, Turkey. Mycotaxon 99: $163-165$.

Aşkun T, Işıloğlu M (1997). Macrofungi of Balya (Balıkesir) County. Turkish Journal of Botany 21(5): 279-284.

Baba H, Alkan S, Kaşık G (2013). Macrofungi of Antakya (Hatay) and Its Environment. The Journal of Fungus 4(1): 11-20.

Baba H, Alkan S, Kaşık G (2014). Macrofungi of Mustafa Kemal University Tayfur Sökmen Campus (Hatay- Turkey) and Environment. The Journal of Fungus 5(2): 1-8.

Baydar S, Sesli E (1994). The macromycetes determined in Akçaabat District of Trabzon Province. Turkish Journal of Botany 18: 99-101.

Bessette AE, Bessette AR, Fischer DW (1997). Mushrooms of Northeastern North America. Hong Kong: Syracuse University Press.

Bessette AE, Miller OK, Bessette AR, Miller HH (1995). Mushrooms of North America in Colour. A field Guide Companion to Seldom-Illustrated Fungi. Hong Kong: Syracuce University Press.

Breitenbach J, Kränzlin F (1986). Fungi of Switzerland, Volume 2: Non Gilled Fungi. Lucerne: Verlag Mykologia.

Buczacki S (2012). Collins Fungi Guide. The most complete field guide to the mushrooms and toadstools of Britain \& Ireland. Hong Kong: Harper Collins Publishers.

Demirel K, Uzun Y (2004). Two new records of Phallales for the mycoflora of Turkey. Turkish Journal of Botany 28(1-2): 213214.

Ellis MB, Ellis JP (1990). Fungi Without Gills (Hymenomycetes and Gasteromycetes). An Identification Handbook. London: Chapman and Hall.

Gaona MGC, Trierveiler-Pereira L, Cano YEM (2017). New records of Phallales from Paraguay. Mycotaxon 132: $361-372$.

Gücin F (1990). Elazı̆̆ Çevresinde Belirlenen Makrofunguslar. Doga Türk Botanik Dergisi 14(3): 171-177.

Günay N, Demirel K (2006). Düziçi ve Bahçe (Osmaniye) Yöresinde Yetişen Makrofunguslar Üzerinde Taksonomik Bir Araştırma. Yüzücü Y1l Üniversitesi Fen Bilimleri Enstitüsü Dergisi 11(1): 17-24.

Güngör H, Solak MH, Allı H, Işıloğlu M, Kalmış E (2016). Contributions to the macrofungal diversity of Muğla Province (Turkey). Mycotaxon 131(1): 255-256.

Index Fungorum (2019). http://www.indexfungorum.org/Names/Names.asp. Accessed 10 June 2019.

Işıloğlu M (1997). Macrofungi of Sarıçiçek yaylası (Malatya). Turkish Journal of Botany 21(1): 63-65.

Işıloğlu M (2001). The macrofungi of Sandras mountain (Muğla). Selçuk Üniversitesi Eğitim Fakültesi Fen Bilimleri Dergisi 9: 127-136.

Işıloğlu M, Öder N (1995a). Macrofungi of Malatya Province. Turkish Journal of Botany 19: 321 -324.

Işıloğlu M, Öder N (1995b). Contributions to the macrofungi of Mediterranean Turkey. Turkish Journal of Botany 19: $603-609$.

Jordan M (1995). The Encyclopedia of Fungi of Britain and Europe. UK: David \& Charles Book. 
Kaşık G, Öztürk C, Türkoğlu A, Doğan HH (2002). Macrofungi flora of Yeşilhisar district (Kayseri). The Herb Journal of Systematic Botany 9(2): 123-134.

Kaya A (2000). Muş ve Bitlis Yörelerinde Tespit Edilen Yenen Makrofunguslar, Türkiye VI. Yemeklik Mantar Kongresi 2-22 Eylül 2000, Bildiri Kitapçı̆̆ı: 112-115.

Kaya A (2009). Macromycetes of Kahramanmaraş province (Turkey). Mycotaxon 108: 31-34.

Kirk PM, Cannon PF, Minter DW, Stalpers JA (2008). Dictionary of the Fungi. 10th ed. Wallingford, UK: CAB International.

Lincoff GH (1981). National Audubon Society Field Guide to North American Mushrooms (National Audubon Society Field Guides).New York: Alfred A. Knopf.

McKnight KH, McKnight VB (1987). A Field Guide to Mushrooms of North America. The Peterson Field Guide Series. New York: Houghton Mifflin Company.

Miller OK, Miller HH (1988). Gasteromycetes Morphological and Developmental Features with Keys to Orders, Families and Genera. Eureka: Mad River Press.

Öztürk C, Kaşık G, Doğan HH, Aktaş S (2003). Macrofungi of Alanya district. Turkish Journal of Botany 27(4): 303-312.

Pegler DN, Læssøe T, Spooner BM (1995). British Puffballs, Earthstars, and Stinkhorns. An Account of the British Gasteroid Fungi. Kew: Royal Botanic Gardens, Kew.

Pekşen A, Karaca GH (2003). Macrofungi of Samsun Province. Turkish Journal of Botany 27(3): 173-184.

Philips R (2010). Mushrooms and Other Fungi of North America. Ontario: Firefly Books.

Roberts P, Evans S (2013). The Book of Fungi. A Life-Size Guide to Six Hundred Species from Around the World. UK: Ivy Press.

Sesli E (2007). Preliminary checklist of macromycetes of the East and Middle Black Sea regions of Turkey. Mycotaxon 99: 7174.

Sesli E, Denchev CM (2014). Checklists of the myxomycetes, larger ascomycetes, and larger basidiomycetes in Turkey. 6th edn. Mycotaxon Checklists Online. (http://www.mycotaxon.com/resources/checklists/sesli-v106-checklist.pdf): 1-136.

Solak MH, Allı H, Işıloğlu M, Güngör H, Kalmış E (2014). Contributions to the macrofungal diversity of Antalya Province. Turkish Journal of Botany 38(2): 386-397.

Solak MH, Yılmaz Ersel F (2005). Macrofungi of Muğla Province. Afyon Kocatepe University Journal of Science 5(1-2): 15-24.

Solak MH, Yılmaz Ersel F, Gücin F, Işıloğlu M (2002). Macrofungi of Balıkesir Province from Turkey. Bio-Science Research Bulletin 18(2): 137-149.

Sterry P, Hughes B (2009). Collins Complete Guide to British Mushrooms and Toadstools. London: HarperCollinsPublishers Ltd.

Türkoğlu A (2008). Macrofungal diversity of Babadağ (Denizli, Turkey). African Journal of Biotechnology 7(3): 192-200.

Türkoğlu A, Yağız D (2012). Contributions to the macrofungal diversity of Uşak Province. Turkish Journal of Botany 36(5): 580589.

Ünal G, Türkoğlu A, Yaratanakul Güngör M. 2016. Muğla Yöresindeki Eucalyptus Ormanlarında Yetişen Makrofunguslar Üzerine Taksonomik Çalışmalar. Türk Tarım - Gıda Bilim ve Teknoloji Dergisi 4(3): 244-247.

Uzun Y, Acar İ, Akçay ME, Kaya A (2017). Contributions to the macrofungi of Bingöl, Turkey. Turkish Journal of Botany 41(5): 516-534.

Vlaev K (1915). Contribution to the higher fungus flora of Turkish Thrace. Travaux de la Société Bulgare des Sciences Naturelles 8: 199-207.

Watling R (1973). Identification of Larger Fungi. UK:Hulton Educational Publications Ltd.

Yağız D, Afyon A, Konuk M, Helfer S (2006b). Contributions to the macrofungi of Kastamonu Province, Turkey. Mycotaxon 98:177-180.

Yağız D, Afyon A, Konuk, Helfer S (2006a). Contributions to the macrofungi of Bolu and Düzce Provinces, Turkey. Mycotaxon 95: 331-334.

Y1lmaz Ersel F, Solak MH (2004). Contributions to the macrofungi of İzmir Province. Turkish Journal of Botany 28(5): 487-490.

Cite this article: Yakar S, Uzun Y, Kaya A (2019). Contributions to the distribution of Phallales in Turkey. Anatolian Journal of Botany 3(2): 51-58. 